\title{
Removal of lead(II) from aqueous solution using date seed-derived biochar: batch and column studies
}

\author{
Zainab Mahdi ${ }^{1}$ D $\cdot$ Qiming J. Yu ${ }^{1} \cdot$ Ali El Hanandeh ${ }^{1}$
}

Received: 14 May 2017 / Accepted: 18 September 2018 / Published online: 25 September 2018

(c) The Author(s) 2018

\begin{abstract}
This study explored the adsorption of lead ion from aqueous solution onto biochars produced from date seed biomass. Initial evaluation of nine date seed-derived biochars showed that biochar prepared at $550{ }^{\circ} \mathrm{C}$ and heating time of $3 \mathrm{~h}$ (DSB550-3) was the best adsorbent for $\mathrm{Pb}^{2+}$ ion removal. Therefore, it was selected for further investigation in batch and column experiments. The effects of contact time, initial $\mathrm{Pb}^{2+}$ concentration, and solution $\mathrm{pH}$ were studied. Solution $\mathrm{pH}$ showed strong effect on the adsorption ability of DSB550-3 biochar to the lead ion, and the maximum adsorption capacity was found to occur around $\mathrm{pH}$ 6.0. The batch maximum adsorption capacity of DSB550-3 biochar was $0.360 \mathrm{mmol} \mathrm{g}^{-1}$. The equilibrium data were adequately fitted to Freundlich and Langmuir isotherms $\left(R^{2}=0.97\right)$. The adsorption kinetics were best described by pseudo-second-order model $\left(R^{2}=0.94\right)$. The breakthrough curve obtained from the column experiment was best described by the modified dose-response model $\left(R^{2}=0.95\right)$. The desorption efficiencies of $\mathrm{Pb}^{2+}$ were $2.1 \%, 23 \%, 12 \%$, and $55 \%$ for DI water, $0.1 \mathrm{M} \mathrm{HCl}, 0.1 \mathrm{M} \mathrm{CaCl}_{2}$, and a combination of $0.1 \mathrm{M} \mathrm{HCl}+0.1 \mathrm{M} \mathrm{CaCl}_{2}$ eluents, respectively. FTIR analysis and batch experiments results suggested that $\mathrm{Pb}^{2+}$ adsorption mechanism was dominated by complexation with active surface groups, precipitation, and cation exchange. Experimental and model results suggested that date seed-derived biochar has high adsorption capacity for $\mathrm{Pb}^{2+}$ compared to other plant-based biochars reported in other literature.
\end{abstract}

Keywords Adsorption $\cdot$ Biochar $\cdot$ Date seed $\cdot$ Desorption $\cdot$ Isotherms $\cdot$ Lead

\section{Introduction}

Heavy metals such as lead are highly toxic chemicals that can cause harmful effects to humans and the environment. Lead can enter the ecosystem from natural sources as well as industrial activities such as petroleum refining, electrical and electronic products, and mining. World and Health Organization (WHO) has identified lead as 1 of 10 top toxic pollutants of major public health concern around the world impacting 18-22 million people globally (Liu et al. 2017). Lead can cause severe damage to the nervous system, kidney, brain, and reproductive system (Goel et al. 2005).

Electronic supplementary material The online version of this article (https://doi.org/10.1007/s13201-018-0829-0) contains supplementary material, which is available to authorized users.

Zainab Mahdi

Zainab.mahdi@griffithuni.edu.au

1 Griffith School of Engineering and Build Environment, Nathan Campus, Griffith University, Nathan, QLD 4111, Australia
Accordingly, the Australian drinking water guidelines set the maximum allowable $\mathrm{Pb}^{2+}$ concentration to less than $0.01 \mathrm{mg} \mathrm{L}^{-1}$ (NHMRC 2015).

A variety of physicochemical treatment methods have been developed to control or remove lead from aqueous solutions including ion exchange, chemical precipitation, and membrane separation. Among these methods, adsorption using activated carbon (AC) has been generally recognized as one of the convenient and effective treatment method for $\mathrm{Pb}^{2+}$ removal. However, the cost of $\mathrm{AC}$ is relatively high. These challenges prompted researchers to investigate more economical, sustainable, and eco-friendly adsorbents to substitute AC for heavy metal removal (El Hanandeh et al. 2016). Biochar application for environmental remediation is an attractive alternative because of the abundance of lowcost biomass that can be used for biochar production. Furthermore, biochar cost is six times cheaper than AC due to the lower energy requirement and the fact that it can be used without further chemical or physical activation (McCarl et al. 2009; Alhashimi and Aktas 2017). 
Biochar is a carbon-rich material derived from thermal decomposition of organics under oxygen-limited condition. Various precursors have been used for biochar preparation including agricultural waste such as rice husk, pinewood, and sugarcane bagasse (Liu and Zhang 2009; Inyang et al. 2011). Agricultural waste is considered a good source for biochar preparation because they are cheap, safe, renewable, and readily available (Ahmed and Theydan 2012). Although various precursors have been used as potential candidate for biochar preparation, works related to utilization of date seeds as suitable low-cost biochar is limited. Therefore, the present work attempts to assess the adsorption ability of biochar derived from date seed for lead ion removal from aqueous solution.

Date palm tree (Phoenix Dactylifera L.) is cultivated in arid and semi-arid regions. It has high tolerance to water shortage and extreme hot temperature. According to the latest statistical data of Food and Agricultural Organization (FAO 2014), the total world production of date was about 8.897 billion tons. Date palm industry is rapidly expanding worldwide, and approximately $35 \mathrm{~kg}$ of palm residues per tree is generated annually (Nasser et al. 2016). Date seed biomass is non-edible waste which represents about onethird of the date weight (Sait et al. 2012) making them the largest agricultural by-product in palm-growing countries. Therefore, finding ways to use this agricultural waste sustainably will benefit date producers by creating value-added product as well as offer an environmentally sound waste management option.

Date seed can be introduced as good candidate material to prepare high-quality biochar for heavy metal adsorption from aqueous solution because of its physicochemical properties. Date seed is a carbon-rich material with chemical compositions of lignin, cellulose, hemicellulose, proteins, and hydrocarbons. The lignin contents of the date seed are very high when compared to that of either softwoods or hardwoods (Nasser et al. 2016). Also, the hemicellulose contents of date seed were relatively like those reported by Bledzki et al. (2010) for typical hardwood materials such as coconut shell. The cellulose and hemicellulose have average per cent elemental compositions of $44.4 \%$ carbon, $49.4 \%$ oxygen, and $6.2 \%$ hydrogen (Ahmad et al. 2012). Lignin has a three-dimensional polymer of phenylpropane units linked together by $\mathrm{C}-\mathrm{O}-\mathrm{C}$ or $\mathrm{C}-\mathrm{C}$ bonds making its elemental composition to be higher in carbon $(62 \%)$ and lower in oxygen (32\%) (Jibril et al. 2008). The high contents of acids of the seeds such as oleic acid are between 41.1 and $58.8 \%$ (Al-Shahib and Marshall 2003), which suggests that the seeds are rich with various surface functional groups such as alcohols, phenolic hydroxides, and ethers. Furthermore, date seed is characterized by its low ash content and high volatile matter and therefore, much surface area is generated due to loss of volatile organic matters during pyrolysis process. Hence, the conversion of date seed into high-quality biochar provides a new solution to the recycle and reuse of non-edible waste to produces valuable products (i.e. biochar) for environmental applications.

Recently, date seed biomass has received considerable attention as a lignin origin for preparing activated carbon (El-Naas et al. 2010). Several studies have examined date seed activated carbon for adsorption purposes (Girgis and El-Hendawy 2002; Bouchelta et al. 2008; Alhamed and Bamufleh 2009; El-Hendawy 2009). Our previous work showed that date seed biochar is characterized by relatively considerable specific surface area, well-developed porous structure, and the presence of various surface functional groups (Mahdi et al. 2016). Furthermore, it showed good adsorption ability for methylene blue (MB) removal from aqueous solution.

Therefore, the present work attempted to assess the adsorption potential of date seed-derived biochar for lead ion removal from aqueous solution. Additionally, most studies encountered in the literature about biochar adsorption were carried out in batch mode which, although provides useful information on adsorption parameters, is not the most practical application in wastewater treatment. Therefore, column experiment was also conducted to provide further information about the adsorption behaviour. The aim of this study was to evaluate the adsorption potential of biochar prepared from date seed under various pyrolysis conditions for $\mathrm{Pb}^{2+}$ removal. The equilibrium isotherms, uptake kinetics, column dynamics, and the mechanisms of $\mathrm{Pb}^{2+}$-biochar interaction were investigated in depth.

The objectives of the study were:

- Investigate the $\mathrm{Pb}^{2+}$ adsorption capacity of biochar prepared at different pyrolysis conditions.

- Identify optimal biochar preparation conditions to achieve maximize $\mathrm{Pb}^{2+}$ adsorption from lead solutions.

- Identify optimal process conditions to maximize adsorption of $\mathrm{Pb}^{2+}$ on biochar using batch experiments.

- Investigate the adsorption of $\mathrm{Pb}^{2+}$ from aqueous solutions in column experiments.

- Study the leaching potential of $\mathrm{Pb}^{2+}$ from loaded biochar.

\section{Materials and methods}

\section{Chemicals}

All the chemicals used in the experiments were of analytical reagent grade. A $5.0 \mathrm{mM} \mathrm{Pb}^{2+}$ stock solution was prepared by dissolving $1.656 \mathrm{~g}$ of $\mathrm{Pb}\left(\mathrm{NO}_{3}\right)_{2}$ in $1.0 \mathrm{~L}$ of deionized water (DI). Then, dilutions of different concentrations ranging from 0.3 to $4.0 \mathrm{mM}$ were prepared. The initial $\mathrm{pH}$ of the 
solutions was adjusted as needed using $0.1 \mathrm{M} \mathrm{NaOH}$ and $0.1 \mathrm{M} \mathrm{HCl}$.

\section{Biochar preparation}

Date fruit of full ripeness (Khalas cultivar) was used. The seeds were washed, dried, and then placed in covered crucibles and purged with $\mathrm{N}_{2}$ gas to provide a low oxygen environment then placed inside a muffle furnace (Lenton furnace). Nine sets of biochars were prepared by varying pyrolysis temperature $\left(350,450\right.$, and $\left.550{ }^{\circ} \mathrm{C}\right)$ and heating time $(1,2$, and $3 \mathrm{~h})$. Biochar samples were washed with deionized water to remove fine particles and then crushed and sieved to particle size in the range from 0.6 to $1.4 \mathrm{~mm}$. All the biochars were labelled according to their pyrolysis temperature and heating time (DSBTemp-Time): DSB350-1, DSB350-2, DSB350-3, DSB450-1, DSB450-2, DSB450-3, DSB550-1, DSB550-2, and DSB550-3.

\section{Biochar characterization}

Scanning electron microscope (SEM JEOL JSM-6510) was used to examine the surface morphology of biochar before and after $\mathrm{Pb}^{2+}$ adsorption. FTIR analysis of the biochar before and after $\mathrm{Pb}^{2+}$ adsorption was conducted using (PerkinElmer Spectrum two) to determine the surface functional groups onto the biochar surface. Boehm titration method was used to quantify the acidic functional groups onto biochar surface (Boehm 2002). The $\mathrm{pH}$ of biochar was determined according to ASTM D6851 method (ASTM 2011). Biochar specific surface area was determined using methylene blue adsorption (Nunes and Guerreiro 2011). Water-extractable cations and CEC were analysed with a sequential water- $\mathrm{BaCl}_{2}$ extraction following Kloss et al. (2012) method. Further details on the biomass and biochar physicochemical characteristics are found in our previous work (Mahdi et al. 2016).

\section{Batch adsorption experiments}

\section{Screening of different biochars}

Biochars prepared at different pyrolysis conditions were screened to compare adsorption uptake capacity of $\mathrm{Pb}^{2+}$ from aqueous solution. Biochar $(0.10 \mathrm{~g})$ was mixed with $10 \mathrm{~mL}$ of $\mathrm{Pb}^{2+}$ solution (initial concentration of $0.50 \mathrm{mM}$ ) in $50 \mathrm{~mL}$ glass container. The initial solution $\mathrm{pH}$ was adjusted to 6.0 by adding $0.10 \mathrm{M} \mathrm{NaOH}$ or $\mathrm{HCl}$. The mixture was shaken using rotary shaker at $30 \mathrm{rpm}$ for $24 \mathrm{~h}$. Then, the mixture was separated using a $0.45 \mu \mathrm{m}$ Millex ${ }^{\circledR}$ syringe filter. The final concentration of $\mathrm{Pb}^{2+}$ was determined using atomic absorption spectroscopy (Avanta-GBC). The amount of $\mathrm{Pb}^{2+}$ adsorbed on the biochar $q_{\mathrm{e}}\left(\mathrm{mmol} \mathrm{g}^{-1}\right)$ is determined by Eq. (1):

$q_{\mathrm{e}}=\frac{\left(C_{\mathrm{o}}-C_{\mathrm{e}}\right) V}{W}$

where $C_{\mathrm{o}}$ is the initial $\mathrm{Pb}^{2+}$ concentration $(\mathrm{mM}), C_{\mathrm{e}}$ is the $\mathrm{Pb}^{2+}$ concentration at equilibrium $(\mathrm{mM}), V$ is the solution volume $(\mathrm{L})$, and $W$ is the biochar dosage $(\mathrm{g})$.

A control run of adsorption experiment was also carried out to investigate the effect of glassware and sampling instruments and showed that the quantity of $\mathrm{Pb}^{2+}$ adhering on the container walls and other instruments were negligible $(3.65 \pm 0.84 \%)$. Adsorption performance of date seed biomass in their native form was also investigated and compared to the biochar. All experiments were repeated three times under the same conditions and average values were reported.

\section{Effect of solution $\mathrm{pH}$ on adsorption}

Solution $\mathrm{pH}$ was investigated in the range of $2.0-6.0$ by mixing $0.10 \mathrm{~g}$ of biochar with $10 \mathrm{~mL}$ of $\mathrm{Pb}^{2+}$ solution at initial concentration of $0.50 \mathrm{mM}$ in $50 \mathrm{~mL}$ glass container. The initial $\mathrm{pH}$ of the solution was adjusted using $0.1 \mathrm{M}$ of $\mathrm{NaOH}$ or $\mathrm{HCl}$ as required. The mixture was shaken using rotary shaker at $30 \mathrm{rpm}$ for $24 \mathrm{~h}$ at room temperature $\left(23 \pm 2{ }^{\circ} \mathrm{C}\right)$, then the mixture was separated, and the final concentration of $\mathrm{Pb}^{2+}$ was determined. Above $\mathrm{pH}$ 6.0, precipitations become an issue; therefore, $\mathrm{pH}$ values above 6.0 were not studied.

\section{Adsorption isotherms experiments}

The $\mathrm{Pb}^{2+}$ uptake onto biochar as function of metal concentration was studied by varying $\mathrm{Pb}^{2+}$ concentration while keeping all other parameters constant. The experiments were conducted by mixing $0.10 \mathrm{~g}$ biochar samples with $10 \mathrm{~mL}$ of $\mathrm{Pb}^{2+}$ solutions at initial concentrations in the range $0.3-4.0 \mathrm{mM}$ using $50 \mathrm{~mL}$ glass container. The experiments were performed at room temperature $\left(23 \pm 2{ }^{\circ} \mathrm{C}\right)$ and $\mathrm{pH} 6.0$. The mixture was shaken for $24 \mathrm{~h}$ at $30 \mathrm{rpm}$, and then it was separated using a $0.45 \mu \mathrm{m}$ Millex ${ }^{\circledR}$ syringe filter. The amount of $\mathrm{Pb}^{2+}$ adsorbed on the biochar $q_{\mathrm{e}}\left(\mathrm{mmol} \mathrm{g}^{-1}\right)$ is determined using Eq. (1). The relationship between the amounts of metal adsorbed $\left(q_{\mathrm{e}}\right)$ and metal concentrations $\left(C_{\mathrm{e}}\right)$ at equilibrium was described by Langmuir, Freundlich, and the Temkin isotherms models as shown in Table 1 (see supplementary sheet for further detail).

The thermodynamic equilibrium of $\mathrm{Pb}^{2+}$ adsorption was obtained at $25^{\circ} \mathrm{C}$ by calculating the Gibbs free energy $\left(\Delta G^{\circ}\right)$ for the adsorption process Eq. (2) (Anastopoulos and Kyzas 2016):

$\Delta G=-R T \ln \left(K_{L} \times 55.5 \times 10^{3}\right)$

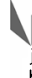


Table 1 Adsorption equilibrium isotherms

\begin{tabular}{lll}
\hline Isotherm & Equation & Description \\
\hline Langmuir isotherm & $q_{\mathrm{e}}=\frac{q_{\max } K_{L} C_{\mathrm{e}}}{1+K_{L} C_{\mathrm{e}}}$ & It proposes a monolayer adsorption onto a surface with a finite number of identical sites \\
Freundlich isotherm & $q_{\mathrm{e}}=K_{F} C_{\mathrm{e}}^{\frac{1}{n}}$ & It is based on adsorption onto a heterogeneous surface \\
Temkin isotherm & $q_{\mathrm{e}}=\frac{R T}{b} \ln \left(A C_{\mathrm{e}}\right)$ & $\begin{array}{c}\text { It proposes that the adsorption heat of all the molecules in the layer would decrease } \\
\text { linearly with coverage due to adsorbent-adsorbate interactions }\end{array}$ \\
\hline
\end{tabular}

where $\Delta G^{\circ}$ is the change in free energy $\left(\mathrm{kJ} \mathrm{mol}^{-1}\right), K_{L}$ is the equilibrium constant, $R$ is the gas constant $\left(8.314 \mathrm{~J} \mathrm{~K}^{-1}\right.$ $\left.\mathrm{mol}^{-1}\right), T$ is the absolute temperature $(\mathrm{K})$, and $55.5\left(\mathrm{~mol} \mathrm{~L}^{-1}\right)$ is the water concentration.

\section{Adsorption kinetics}

The kinetics experiments were performed by mixing $1.0 \mathrm{~g}$ of the biochar with $100 \mathrm{~mL}$ of $\mathrm{Pb}^{2+}$ solution at initial concentration of $0.5 \mathrm{mM}$, and the solution $\mathrm{pH}$ was kept at 6.0. The mixture was shaken for $1440 \mathrm{~min}$ using rotary shaker at $30 \mathrm{rpm}$. Samples were drawn at specified time intervals and analysed. The amount of $\mathrm{Pb}^{2+}$ adsorbed at time $q_{\mathrm{t}}\left(\mathrm{mmol} \mathrm{g}^{-1}\right)$ was calculated as:

$q_{\mathrm{t}}=\frac{\left(C_{\mathrm{o}}-C_{\mathrm{t}}\right) V}{W}$

where $C_{\mathrm{o}}$ is the initial $\mathrm{Pb}^{2+}$ concentration $(\mathrm{mM}), C_{\mathrm{t}}$ is the $\mathrm{Pb}^{2+}$ concentration at given time $t(\mathrm{mM}), V$ is the solution volume $(\mathrm{L})$, and $W$ is the biochar weight $(\mathrm{g})$. To explore the adsorption mechanisms of $\mathrm{Pb}^{2+}$ uptake onto DSB550-3 biochar, the common kinetic models such as the pseudofirst-order and pseudo-second-order kinetics models were applied to fit the experimental data.

The linearized form of pseudo-first-order model is given as below:

$\ln \left(q_{\mathrm{e}}-q_{\mathrm{t}}\right)=\ln q_{\mathrm{e}}-k_{1} t$

where $q_{\mathrm{e}}$ and $q_{\mathrm{t}}$ are the amount of $\mathrm{Pb}^{2+}$ adsorbed $\left(\mathrm{mmol} \mathrm{g}^{-1}\right)$ at equilibrium and at time $t$, respectively. $k_{1}\left(\mathrm{~min}^{-1}\right)$ is the pseudo-first-order adsorption rate constant. The values of $k_{1}$ and $q_{\mathrm{e}}$ are obtained from the slopes and intercepts of the linear plot of $\ln \left(q_{\mathrm{e}}-q_{\mathrm{t}}\right)$ against $t$.

A pseudo-second-order kinetic model is expressed in linearized form as in Eq. (5):

$\frac{t}{q_{\mathrm{t}}}=\frac{1}{k_{2} q_{\mathrm{e}}^{2}}+\frac{t}{q_{\mathrm{t}}}$
The second-order rate constant $k_{2}$ and $q_{\mathrm{e}}$ are obtained from the intercept and the slope of the plot obtained by plotting $t / q$ against time $t$.

\section{Column adsorption experiments}

Column adsorption studies were carried out using glass column of $50 \mathrm{~cm}$ length and $2.5 \mathrm{~cm}$ internal diameter fitted with a suction filter. To avoid air entrapment, pre-wetted DSB550-3 biochar (bulk density of $490 \mathrm{~kg} \mathrm{~m}^{-3}$ ) was packed up with $12 \mathrm{~g}$ biochar to the desired bed height $(5 \mathrm{~cm})$. The biochar bed was supported by $1 \mathrm{~cm}$ layer of glass beads (2.0 mm diameter). Metal solution of $0.5 \mathrm{mM}$ concentration and initial $\mathrm{pH}$ of 6.0 was then percolated through the

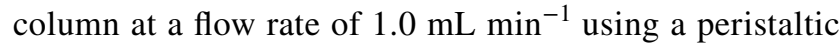
pump (Masterflex L/S-Cole/Palmer). The effluent samples at the outlet of the column were collected at regular time intervals, and the column was operated until the concentration of metal effluent exceeded $95 \%$ of its initial concentration. The experiments were performed in duplicate at room temperature.

The value of the total mass of metal adsorbed, $q_{\mathrm{t}}(\mathrm{mmol})$, can be calculated from the area under the breakthrough curve as shown in Eq. (6):

$q_{t}=\frac{Q}{1000} \int_{t=0}^{t=t_{\mathrm{s}}}\left(C_{\mathrm{o}}-C_{\mathrm{t}}\right) \mathrm{d} t$

Equilibrium metal uptake or maximum capacity of the column, $q_{\text {eq }}\left(\mathrm{mmol} \mathrm{g}^{-1}\right)$, in the column is determined by Eq. (7):

$q_{\mathrm{eq}}=\frac{q_{\mathrm{t}}}{m}$

where $m$ is the dry weight of adsorbent in the column $(\mathrm{g})$.

Total amount of metal ion entering column $\left(m_{\mathrm{t}}, \mathrm{mmol}\right)$ is calculated by Eq. (8):

$m_{\mathrm{t}}=\frac{C_{\mathrm{o}} Q t_{\mathrm{s}}}{1000}$ 
The removal percentage $(R \%)$ of lead ions is determined by Eq. (9):

$R \%=\frac{q_{\mathrm{t}}}{m_{\mathrm{t}}} \times 100$

\section{Desorption experiments}

Loaded biochar obtained from the earlier experiments were used to determine the desorption behaviour of $\mathrm{Pb}^{2+}$. Deionised water, $0.1 \mathrm{M} \mathrm{HCl}, 0.1 \mathrm{M} \mathrm{CaCl}_{2}$, and mixture of $0.1 \mathrm{M} \mathrm{HCl}$ and $0.1 \mathrm{M} \mathrm{CaCl}_{2}$ were used as desorption agents. The laden biochar was first rinsed with DI water $(10 \mathrm{~mL})$ to remove any unabsorbed $\mathrm{Pb}^{2+}$ and oven-dried at $50{ }^{\circ} \mathrm{C}$ for $24 \mathrm{~h}$. The quantity of $\mathrm{Pb}^{2+}$ released into DI water was determined using AAS (Avanta-GBC). Then, dried biochar samples $(0.10 \mathrm{~g}$ each) were transferred to a clean flask containing $10 \mathrm{~mL}$ of $0.1 \mathrm{M} \mathrm{HCl}, 0.1 \mathrm{CaCl}_{2}$, or $0.1 \mathrm{M}$ of $50 / 50$ mixture $\left(\mathrm{HCl}+\mathrm{CaCl}_{2}\right)$. The mixture was agitated in rotary shaker at $30 \mathrm{rpm}$ for $24 \mathrm{~h}$. After elution, biochar was filtered to measure the concentration of $\mathrm{Pb}^{2+}$ leached in the solution. The desorption efficiency is determined by Eq. (10):

Desorption $\%=\frac{\text { amount of metal ion desorbed }}{\text { amount of metal ion adsorbed }} \times 100$

\section{Statistical analysis}

Regression analysis was used to investigate correlations between pyrolysis conditions and biochar adsorption of $\mathrm{Pb}^{2+}$ ion. The analysis was performed using SPSS ver. 22 . One-way ANOVA and Tukey post hoc (HSD) tests were also performed to determine the significance of the differences between the adsorption capacities of the biochars prepared at different pyrolysis temperatures and heating time.

\section{Results and discussion}

\section{Initial evaluation for $\mathrm{Pb}^{2+}$ removal}

Figure 1 shows the removal efficiency $(R \%)$ of $\mathrm{Pb}^{2+}$ ion of the different biochars as a function of pyrolysis temperature and heating time. As shown in Fig. 1, biochar prepared at $550{ }^{\circ} \mathrm{C}$ and long heating time $3 \mathrm{~h}$ (DSB550-3) showed highest adsorption of $\mathrm{Pb}^{2+}$ ion among the tested biochars. The adsorption removal efficiency of $\mathrm{Pb}^{2+}$ ion by DSB550-3 was $(96.7 \% \pm 0.84 \%)$. Furthermore, the lowest removal efficiency $(73.1 \% \pm 7.98)$ was observed for DSB350-1 biochar, while the adsorption performance of date seed biomass in their native form had the lowest removal efficiency $(12.8 \% \pm 5.51)$.

The removal rate of $\mathrm{Pb}^{2+}$ ion increased with the increasing pyrolysis temperature and heating time, which is

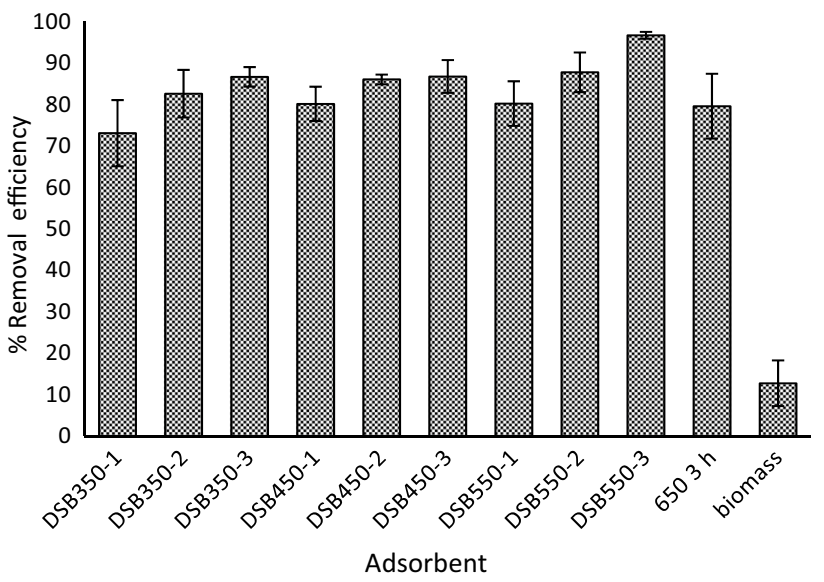

Fig. 1 Adsorption capacity of date seed-derived biochar for $\mathrm{Pb}^{2+}$ removal (initial concentration $=0.5 \mathrm{mM}$; biochar: solution ratio $=10 \mathrm{~g} \mathrm{~L}^{-1}$; time $=24 \mathrm{~h} ; \mathrm{pH} 6$; room temperature; particle size $=0.6-1.4 \mathrm{~mm}$ )

consistent with our findings about methylene blue adsorption on date seed biochars (Mahdi et al. 2016). Our results are also in agreement with Yakkala et al. (2013) who investigated $\mathrm{Pb}^{2+}$ adsorption using biochar derived from buffalo weed at different pyrolysis temperatures (300, 500 and $700{ }^{\circ} \mathrm{C}$ ) and reported that adsorption capacity increased with pyrolysis temperature. This can be attributed to the influence of pyrolysis temperature and heating time on the biochar physicochemical characteristics. Regression analysis showed relatively strong correlation between adsorption capacity and the pyrolysis temperature $(r=0.72)$ and heating time $(r=0.74)$, and these correlations were significant $(p<0.05)$. Furthermore, ANOVA with HSD post hoc analysis revealed that DSB550-3 has significantly higher adsorption capacity for the $\mathrm{Pb}^{2+}$ than all other biochars tested in this study. Because DSB550-3 was the best adsorbent, further investigations were conducted to determine the governing adsorption mechanisms of lead ion on the biochar.

\section{Characteristics of biochar}

The physicochemical properties of biochar significantly affect its heavy metal adsorption ability and thus the mechanisms governing metal removal by biochar ( $\mathrm{Li}$ et al. 2017). The physicochemical properties of the biochars prepared in this study are presented in Table 2 . The carbon content, ash content, surface area, $\mathrm{pH}$, and CEC of the biochars increased with increasing pyrolytic temperature. The increased percentage of the ash content of biochar (6.79-12.67\%) can be attributed to the removal of organic compounds during the pyrolysis. The ash content of biochar samples is positively correlated with biochar $\mathrm{pH}$. Although the $\mathrm{pH}$ of biochars varies considerably with pyrolysis temperature, heating

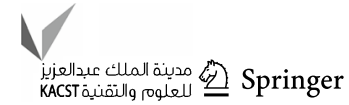


Table 2 Characteristics of biochar prepared at different pyrolysis conditions

\begin{tabular}{lcllllll}
\hline Biochar & $\begin{array}{l}\text { Surface area } \\
\left(\mathrm{m}^{2} \mathrm{~g}^{-1}\right)\end{array}$ & $\mathrm{pH}$ & $\mathrm{C} \%$ & \multicolumn{2}{l}{ Total acidic groups, mmol } & CEC \\
\cline { 5 - 7 } & & & & Carboxyl & Lactone & Phenolic & \\
\hline DSB350-1 & 23.88 & 6.95 & 64.4 & 0.47 & 0.43 & 0.65 & 12.47 \\
DSB350-2 & 69.52 & 6.99 & 66.7 & 0.88 & 0.30 & 0.37 & 14.94 \\
DSB350-3 & 73.78 & 7.48 & 69.0 & 0.55 & 0.35 & 0.50 & 16.86 \\
DSB450-1 & 29.86 & 7.61 & 63.7 & 0.55 & 0.43 & 0.18 & 17.02 \\
DSB450-2 & 97.48 & 7.69 & 71.5 & 0.40 & 0.78 & 0.03 & 20.81 \\
DSB450-3 & 100.2 & 7.79 & 79.3 & 0.40 & 0.68 & 0.03 & 20.70 \\
DSB550-1 & 29.56 & 8.36 & 69.8 & 0.50 & 0.41 & 0.19 & 23.69 \\
DSB550-2 & 88.16 & 8.43 & 76.0 & 0.60 & 0.20 & 0.70 & 21.28 \\
DSB550-3 & 104.2 & 8.58 & 82.2 & 0.50 & 0.40 & 0.30 & 23.60 \\
\hline
\end{tabular}

time, and type of feedstock ( $\mathrm{Li}$ et al. 2017), generally, biochar exhibits alkaline nature (Claoston et al. 2014). A positive relationship has been observed between biochar $\mathrm{pH}$ and pyrolysis temperature as shown in Table 2. This can be attributed to the release of alkali salts from the organic matrix during the pyrolysis process (Chen et al. 2014; Claoston et al. 2014).

Surface area of biochar is the major physical characteristic that influences adsorption capacity of biochar for heavy metal ions removal ( $\mathrm{Li}$ et al. 2017). Biochar surface area varies considerably with pyrolysis temperature and heating time. When biomass is subjected to pyrolysis, volatile organic matter is released and progressively increasing surface area of the resultant biochar (Claoston et al. 2014). Increasing the temperature from 500 to $900{ }^{\circ} \mathrm{C}$, Chen et al. (2014) reported that the surface area of biochar increased from 25.4 to $67.6 \mathrm{~m}^{2} \mathrm{~g}^{-1}$. However, in some cases, biochar produced at high-temperature displays lower surface area due to the destruction or blocking by tar ( $\mathrm{Li}$ et al. 2017). In our case, biochars prepared at low temperatures and short heating times had smaller surface area which may have limited the $\mathrm{Pb}^{2+}$ ions access to the surface-active sites (Table 2).

Biochar mineral composition including potassium $\left(\mathrm{K}^{+}\right)$, calcium $\left(\mathrm{Ca}^{2+}\right)$, magnesium $\left(\mathrm{Mg}^{2+}\right)$, and sodium $\left(\mathrm{Na}^{+}\right)$can also contribute to metal adsorption via cation exchange capacity (Li et al. 2017). In our study, increasing pyrolysis temperature from 350 to $550{ }^{\circ} \mathrm{C}$ led to the increase in total base cations contents in biochar, contributing to increased biochar $\mathrm{pH}$. Furthermore, the disappearance of acidic functional groups such as carboxylic $\mathrm{COOH}$ for biochars prepared at higher pyrolysis temperature is another contributor. At higher temperature, biochar yield is lower with high ash content and thus enriching minerals in biochar. The CEC of biochars pyrolyzed at different pyrolysis conditions is given in Table 2, and the results showed that CEC of biochar increased with the increase in pyrolysis temperature. Biochar with high CEC can exhibit higher tendency to adsorb heavy metal cations by releasing light metal cations like $\mathrm{K}^{+}, \mathrm{Ca}^{2+}$, and $\mathrm{Mg}^{2+}$ (Wang and Liu 2017).
Morphological structure of biochars before and after $\mathrm{Pb}^{2+}$ adsorption was examined using SEM spectra as shown in Fig. 2. The SEM images showed that the roughness of the biochar surface and the size of the pores enhanced with increasing pyrolysis temperature. Similar results were also reported by Chen et al. (2017). In general, biomass rich with lignin content develops macroporous biochar, while biomass rich in cellulose yields a predominantly microporous biochar (Joseph et al. 2007). SEM images after $\mathrm{Pb}^{2+}$ adsorption further revealed that $\mathrm{Pb}^{2+}$ deposition mainly occurred on the biochar surface and in the mesopores rather than micropores. Similar observation was reported by $\mathrm{Han}$ et al. (2013) for $\mathrm{Cu}^{2+}$ and $\mathrm{Zn}^{2+}$ adsorption on switchgrass and woody biochar. This can be due to $\mathrm{Pb}^{2+}$ precipitation on the accessible surfaces as well as bonding to active sites (Chen et al. 2011a, b; Kim et al. 2013).

Surface functional groups of biochar such as carboxylic, amino, and hydroxyl groups play important roles in metal adsorption onto biochar. Boehm titration results showed that the total acidic functional groups on biochar surface decreased with increasing pyrolysis temperature from 350 to $550{ }^{\circ} \mathrm{C}$ (Table 2). This can be attributed to the higher degree of carbonization suggesting decrease in abundances of hydroxyl $(\mathrm{OH})$ and carboxylic $(\mathrm{COOH})$ groups. This is consistent with the increased biochar $\mathrm{pH}$ from 6.95 to 8.58 . Similar observation was also reported by Al-Wabel et al. (2013). Surface functional groups of DSB550-3 biochar before and after $\mathrm{Pb}^{2+}$ adsorption based on the FTIR spectra were identified as shown in Fig. 3. It can be seen from Fig. 3 that absorption band intensities were shifted after $\mathrm{Pb}^{2+}$ adsorption. The shift to higher wave numbers from 1563 to $1678 \mathrm{~cm}^{-1}$ related to the $\mathrm{C}=\mathrm{O}$ stretching vibration after $\mathrm{Pb}^{2+}$ adsorption. This indicates a possible adsorption mechanism involving $\pi-\pi$ interactions between $\mathrm{Pb}^{2+}$ ion and $\mathrm{C}=\mathrm{O}$ in carboxylic and ester groups of biochar ( $\mathrm{Jia}$ et al. 2013). Furthermore, the band peak at approximately $534 \mathrm{~cm}^{-1}$ can be ascribed to the inorganic oxide (Chen et al. 2011b). Therefore, the oxygen-containing functional groups 
Fig. 2 SEM images for DSB550-3 biochar before and after $\mathrm{Pb}^{2+}$ adsorption
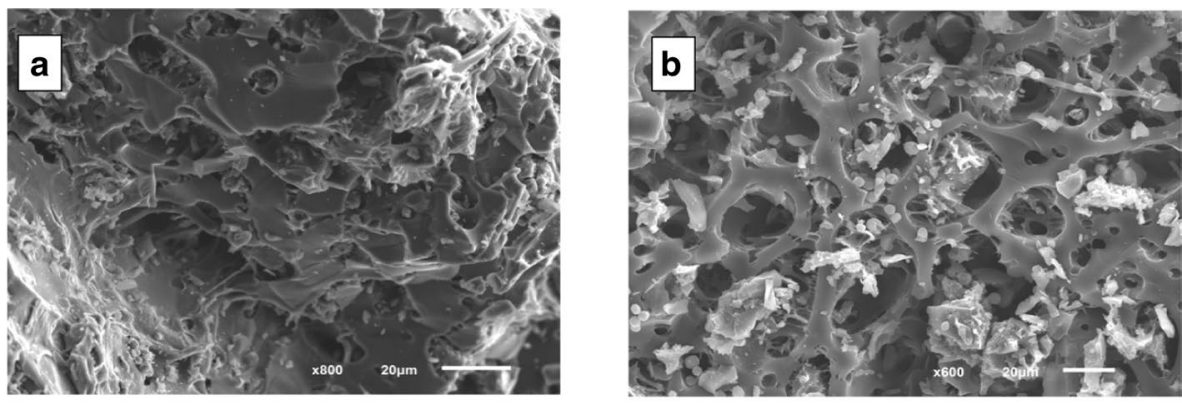

DSB550-3 (a) Before $\mathrm{Pb}^{2+}$ adsorption, (b) after $\mathrm{Pb}^{2+}$ adsorption
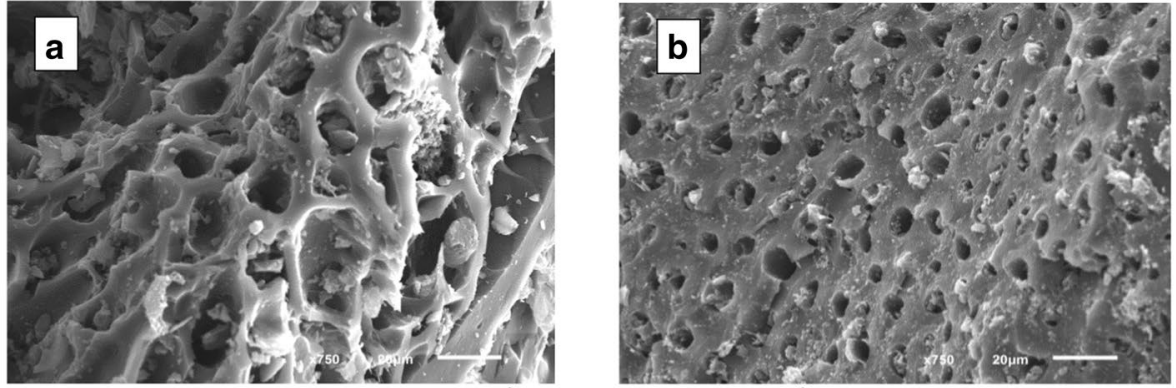

DSB450-3 (a) Before $\mathrm{Pb}^{2+}$ adsorption, (b) after $\mathrm{Pb}^{2+}$ adsorption
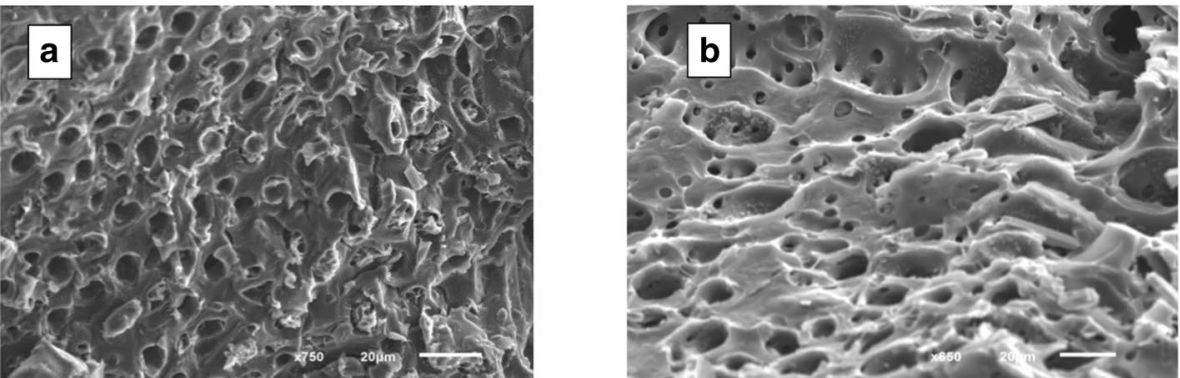

DSB550-2 (a) Before $\mathrm{Pb}^{2+}$ adsorption, (b) after $\mathrm{Pb}^{2+}$ adsorption

onto biochar surface play beneficial role for adsorbing lead ion from aqueous solution.

Based on the above results, the mechanisms controlling $\mathrm{Pb}^{2+}$ removal onto date seed-derived biochar can be identified as complexation with surface functional groups, physical adsorption due to porous structure, metal precipitation, and cation exchange mechanism.

\section{Effect of pH on adsorption}

The adsorption of $\mathrm{Pb}^{2+}$ ion by the DSB550-3 biochar was studied over a $\mathrm{pH}$ range of 2-6, keeping all other parameters constant as shown in Fig. 4. It can be seen from Fig. 4, $\mathrm{Pb}^{2+}$ adsorption increased linearly from $\mathrm{pH} 2$ to 4 , then levelled between $\mathrm{pH} 4$ and 5, before slightly increasing towards $\mathrm{pH} 6$. The maximum $\mathrm{Pb}^{2+}$ adsorption was achieved in the $\mathrm{pH}$ range between 5 and 6 . The maximum "pure" $\mathrm{Pb}^{2+}$ adsorption due to $\mathrm{pH}$ function may have occurred around $\mathrm{pH} 5$. This range is in agreement with other researchers who reported that the highest adsorption of $\mathrm{Pb}^{2+}$ onto date seed activated carbon was achieved within the $\mathrm{pH}$ range 5-6 (Abdulkarim and Abu Al-Rub 2004; Danish et al. 2011). The solution $\mathrm{pH}$ affects the surface charge as well as the speciation of the metal ions (Li et al. 2017). At lower $\mathrm{pH}$, competition for binding sites between $\mathrm{Pb}^{2+}$ and $\mathrm{H}^{+}$results in lower uptake of metal (Bouhamed et al. 2012). The observed increase in adsorption around $\mathrm{pH} 6$ may have been caused by some precipitation as $\mathrm{Pb}(\mathrm{OH})_{2}$ as a result of the solution buffering to $\mathrm{pH}>6$ during agitation due to the high $\mathrm{pH}$ of the biochar. Higher solution $\mathrm{pH}>6.0$ was avoided due to hydrolyse and precipitation of metal ions as $\mathrm{Pb}(\mathrm{OH})_{2}$. Therefore, all the subsequent experiments in this study were carried out at the optimum initial $\mathrm{pH} 6.0$ to achieve maximum $\mathrm{Pb}^{2+}$ removal.

\section{Adsorption kinetics}

Figure 5 shows the effect of contact time on $\mathrm{Pb}^{2+}$ ion removal. It can be seen from the figure that the adsorption rate reached equilibrium within $360 \mathrm{~min}$ and then became practically constant $(24 \mathrm{~h})$. This can be explained by the

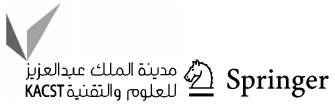


Fig. 3 FTIR spectra before and after $\mathrm{Pb}^{2+}$ adsorption onto the DSB550-3 biochar

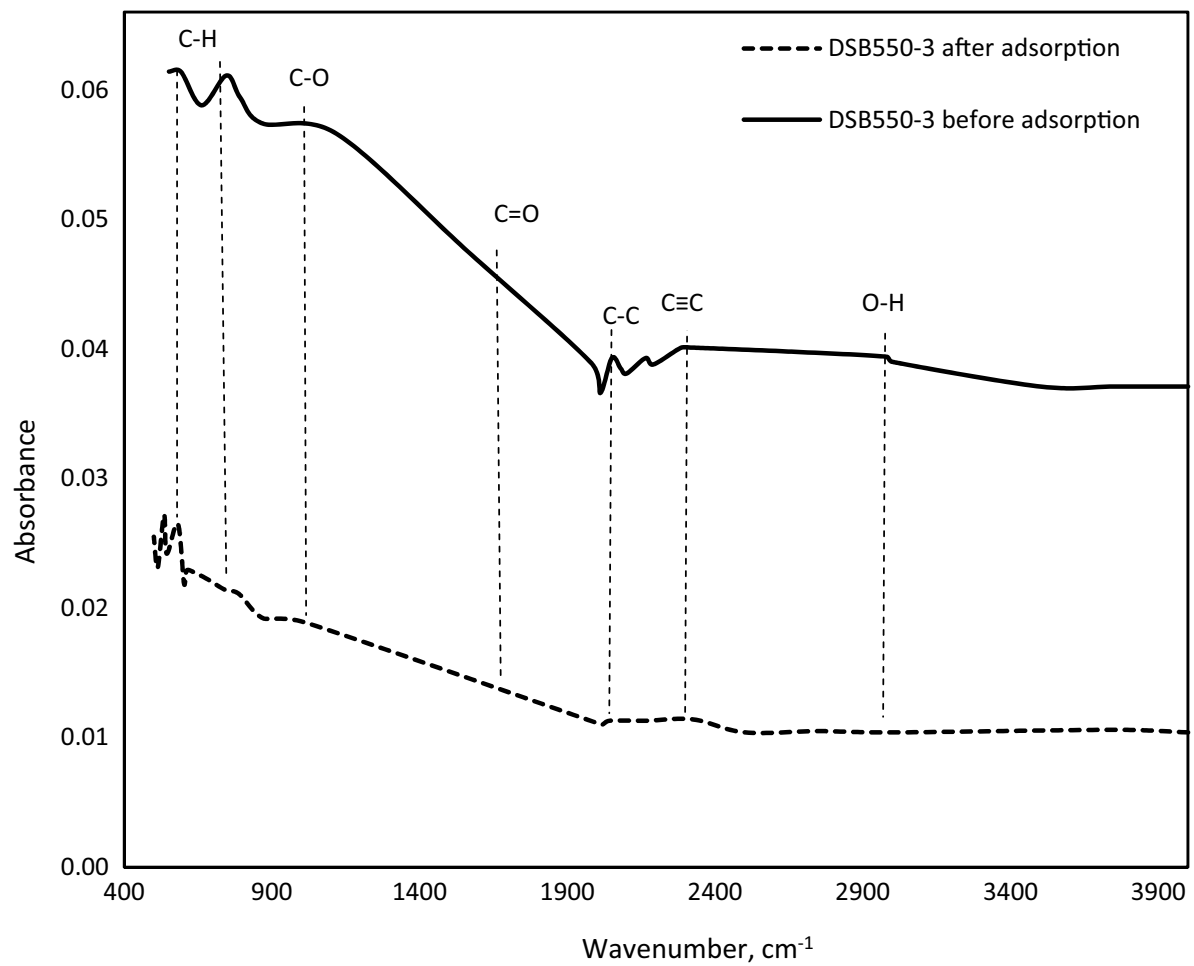

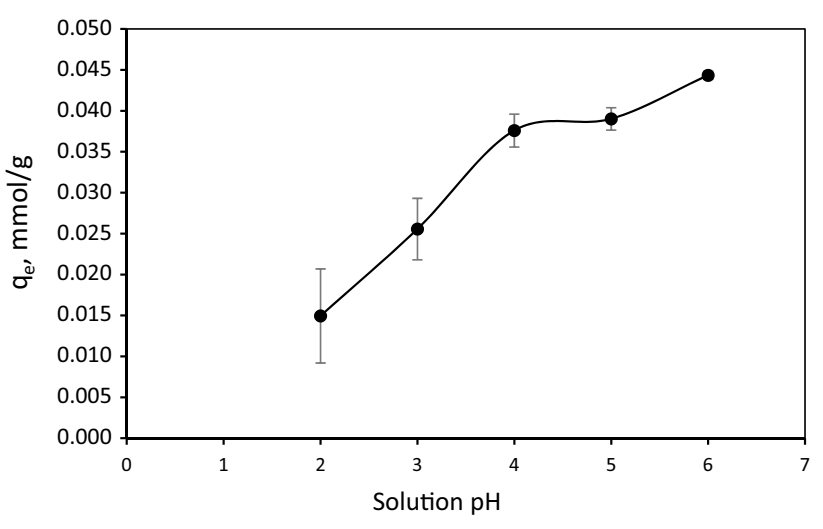

Fig. 4 Effect of solution $\mathrm{pH}$ on $\mathrm{Pb}^{2+}$ adsorption onto DSB550-3 (initial $\mathrm{Pb}^{2+}$ concentration $=0.5 \mathrm{mM}$; temperature $=23 \pm 2{ }^{\circ} \mathrm{C}$; biochar dosage $=10 \mathrm{~g} \mathrm{~L}^{-1}$; particle size $=0.60-1.4 \mathrm{~mm}$ )

availability and accessibility of vacant adsorption sites on the biochar surface. However, as time passed and active sites were occupied, the remaining vacant sites became difficult to access due to physical constraints and repulsion forces (Cheng et al. 2016).

Adsorption kinetics parameters with the correlation coefficients are represented in Table 3. As shown in Fig. 5, the experimental data are better fitted by pseudo-second-order model $\left(R^{2}=0.94\right)$ than other kinetics models. This suggests that chemisorption was the dominant mechanism; primarily involved in inner-sphere complexation and precipitation. This agrees with our observations from the FTIR analysis

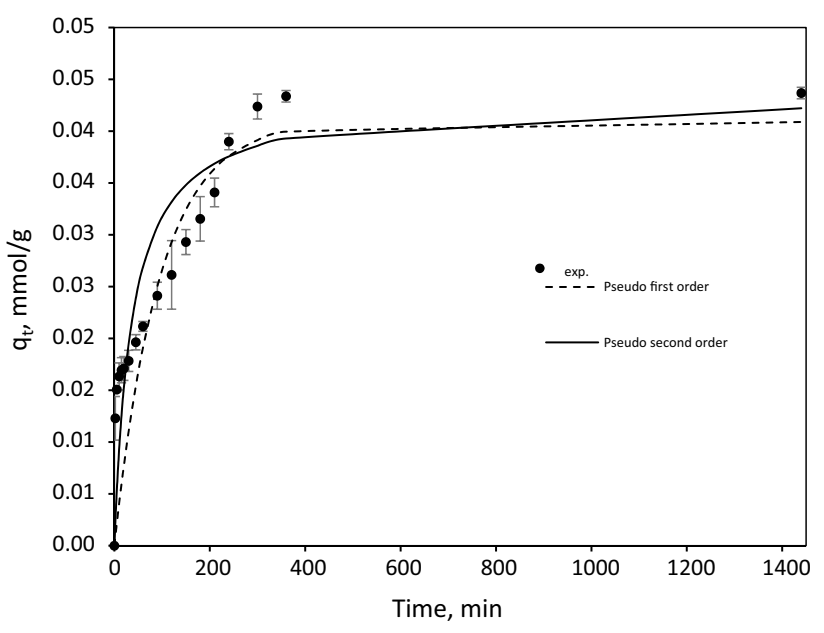

Fig. 5 Effect of contact time on $\mathrm{Pb}^{2+}$ adsorption onto DSB550-3 (initial $\mathrm{Pb}^{2+}$ concentration $=0.5 \mathrm{mM}$; $\mathrm{pH}$ 6; room temperature; biochar: solution ratio $=10 \mathrm{~g} \mathrm{~L}^{-1}$; particle size $=0.6-1.4 \mathrm{~mm}$ )

and the SEM images. The relatively long time required to reach equilibrium (360 $\mathrm{min}$ ) further suggest that electrostatic ion exchange (which commonly reach equilibrium in few minutes) may be comparably small (Zhang and Lo 2006).

\section{Adsorption isotherms}

The amount of $\mathrm{Pb}^{2+}$ adsorbed onto DSB550-3 biochar increased with increasing initial $\mathrm{Pb}^{2+}$ concentrations and 
Table 3 Pseudo-first-order and pseudo-second-order kinetic models parameters for $\mathrm{Pb}^{2+}$ adsorption on DSB550-3 biochar

\begin{tabular}{|c|c|c|c|c|c|c|c|}
\hline \multicolumn{4}{|c|}{ Pseudo-first-order model } & \multicolumn{4}{|c|}{ Pseudo-second-order model } \\
\hline$k_{1} \min ^{-1}$ & $q_{\text {exp. }}\left(\mathrm{mmol} \mathrm{g}^{-1}\right)$ & $q_{\text {calc. }}\left(\mathrm{mmol} \mathrm{g}^{-1}\right)$ & $R^{2}$ & $k_{2}\left(\mathrm{~g} \mathrm{mmol}^{-1} \min ^{-1}\right)$ & $q_{\text {exp. }}\left(\mathrm{mmol} \mathrm{g}^{-1}\right)$ & $q_{\text {calc. }}\left(\mathrm{mmol} \mathrm{g}^{-1}\right)$ & $R^{2}$ \\
\hline 0.011 & 0.044 & 0.041 & 0.86 & 0.632 & 0.044 & 0.042 & 0.94 \\
\hline
\end{tabular}

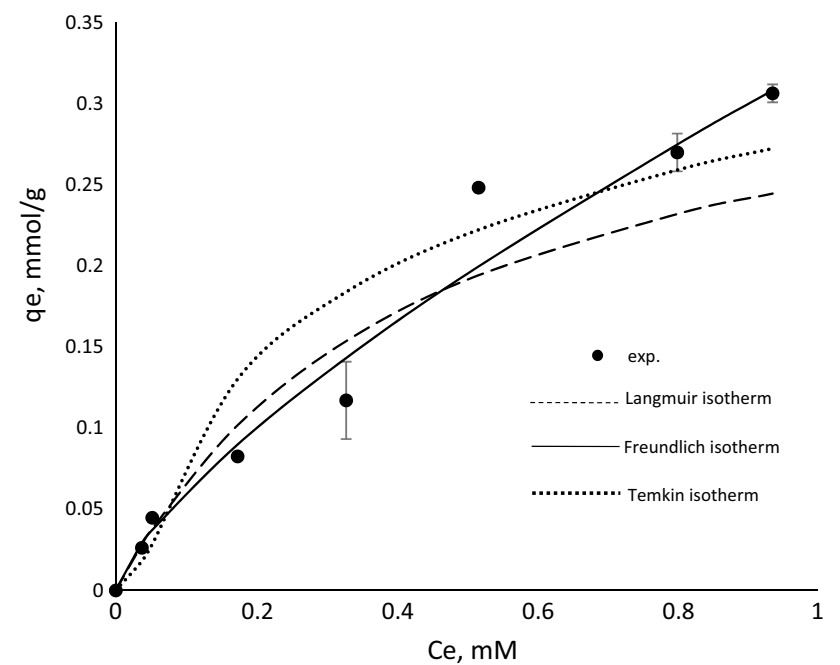

Fig. 6 Equilibrium isotherms of $\mathrm{Pb}^{2+}$ adsorption onto DSB550-3 biochar (initial concentration $=0.3-4.0 \mathrm{mM} ; \mathrm{pH} \mathrm{6}$; time $=24 \mathrm{~h}$; biochar: solution ratio $=10 \mathrm{~g} \mathrm{~L}^{-1}$; particle size $=0.6-1.4 \mathrm{~mm}$ ) finally reached an upper adsorption limit as shown in Fig. 6. This can be attributed to the limited adsorption sites on biochar surface. At lower $\mathrm{Pb}^{2+}$ concentrations, abundant vacant sites were available for $\mathrm{Pb}^{2+}$ to be adsorbed on the biochar. However, as $\mathrm{Pb}^{2+}$ concentration increased in the solution, the adsorption sites on biochar surface were saturated. As shown in Fig. 6, adsorption isotherm was adequately fitted to both Langmuir and Freundlich equations with a correlation coefficient $R^{2}$ of 0.97 . Temkin isotherm showed lower fit to the experimental data $\left(R^{2}=0.88\right)$. Freundlich equation, based on the adsorption intensity value $(n=1.366)$, suggests that the reaction was favourable and that $\mathrm{Pb}^{2+}$ adsorption is more of chemisorption than physical adsorption (El Hanandeh et al. 2016). Peruchi et al. (2015) discussed that for $n>1$, the adsorption occurs on the heterogeneous media where high energy sites were occupied first, followed by adsorption at lower energy sites. Table 4 shows the adsorption isotherms parameters and the correlation coefficients obtained for the linear forms of the isotherms equations.

Table 4 Parameters of adsorption isotherms of $\mathrm{Pb}^{2+}$ on DSB550-3 biochar

\begin{tabular}{|c|c|c|c|c|c|c|c|c|}
\hline \multicolumn{3}{|c|}{ Langmuir isotherm } & \multicolumn{3}{|l|}{ Freundlich isotherm } & \multicolumn{3}{|c|}{ Temkin isotherm } \\
\hline$K_{L}\left(\mathrm{~L} \mathrm{mmol}^{-1}\right)$ & $R^{2}$ & $q_{\max }\left(\mathrm{mmol} \mathrm{g}^{-1}\right)$ & $K_{F}\left[\mathrm{mmol} \mathrm{g}^{-1}\left(\mathrm{~L} \mathrm{mmol}^{-1}\right)^{1 / n}\right]$ & $R^{2}$ & $1 / n$ & $A\left(\mathrm{~L} \mathrm{~g}^{-1}\right)$ & $B\left(\mathrm{~J} \mathrm{~mol}^{-1}\right)$ & $R^{2}$ \\
\hline 2.271 & 0.97 & 0.36 & 0.324 & 0.97 & 0.732 & 26.95 & 0.084 & 0.88 \\
\hline
\end{tabular}

Table 5 Adsorption capacity towards $\mathrm{Pb}^{2+}$ from aqueous solution

\begin{tabular}{|c|c|c|c|c|}
\hline Adsorbent & $\begin{array}{l}\text { Pyrolysis temperature } \\
\left({ }^{\circ} \mathrm{C}\right)\end{array}$ & $\mathrm{pH}$ & $q_{\max }\left[\mathrm{mg} \mathrm{g}^{-1}\left(\mathrm{mmol} \mathrm{g}^{-1}\right)\right]$ & References \\
\hline Date seed biochar & 550 & 6.0 & $74.60(0.360)$ & This study \\
\hline AC from apricot stone & 200 & 6.0 & $22.85(0.110)$ & Kobya et al. (2005) \\
\hline Pinewood biochar & 300 & 5.0 & $4.25(0.021)$ & Liu and Zhang (2009) \\
\hline Rice husk biochar & & & $2.40(0.012)$ & \\
\hline Magnetic pine bark waste char & 950 & 4.0 & $29.69(0.143)$ & Reddy and Lee (2014) \\
\hline AC from coconut shell & - & 4.5 & $26.50(0.128)$ & Sekar et al. (2004) \\
\hline Date palm fibres & - & 4.5 & $18.62(0.090)$ & Al-Haidary et al. (2011) \\
\hline Date palm leaf and trunk (petiole) & & & $20.04(0.097)$ & \\
\hline Coconut shell AC & - & 5.0 & $21.88(0.106)$ & Goel et al. (2005) \\
\hline Digested sugarcane bagasse biochar & - & - & $135.40(0.653)$ & Inyang et al. (2011) \\
\hline Raw sugarcane bagasse biochar & & & $81.90(0.395)$ & \\
\hline Buffalo weed biochar & 700 & 5.0 & $333.33(1.608)$ & Yakkala et al. (2013) \\
\hline
\end{tabular}


Table 5 shows some of the reported values for lead adsorption on different material. It should be noted that comparison is rather difficult due to the varying experimental conditions employed in these studies such as adsorbent properties, $\mathrm{pH}$, temperature, particle size, and metal concentration. Nevertheless, the data suggest that date seed-derived biochar is a promising adsorption material.

\section{Column adsorption studies}

Figure 7 shows the breakthrough curve obtained from the column experiments. The breakthrough time was defined as the point at which the effluent concentration $\left(C_{\mathrm{t}}\right)$ reached about $1 \%$ of the influent concentration $\left(C_{\mathrm{o}}\right)$ and was found to occur at $40 \mathrm{~min}$. The saturation time $\left(t_{\mathrm{s}}\right)$ was defined as the point when the effluent concentration reached $99 \%$ of $C_{\mathrm{o}}$ and was found to occur at $420 \mathrm{~min}$. As shown in Fig. 7, the breakthrough was reached within the first hour. This might have been caused by the high initial concentration which contributed to the abundance of ions causing saturation of the available sites (Maheshwari and Gupta 2016). The relatively broad transfer zone may be attributed to the slow mass transfer rate which is consistent with the relatively long equilibrium time observed in the uptake kinetic curve (Fig. 5). Insufficient bed depth may have also broadened the mass transfer zone and shortened the breakthrough time (Ahmad and Hameed 2010). Qaiser et al. (2009) found that at lower bed depth, axial dispersion is the governing mechanism of mass transfer. Therefore, insufficient bed depth may lead to short residence time that is insufficient for metal ions to diffuse throughout the bed.

From the breakthrough curve, the total removal $(R \%)$ and the equilibrium adsorption capacity $\left(q_{\mathrm{eq}}, \mathrm{mmol} \mathrm{g}^{-1}\right)$ were

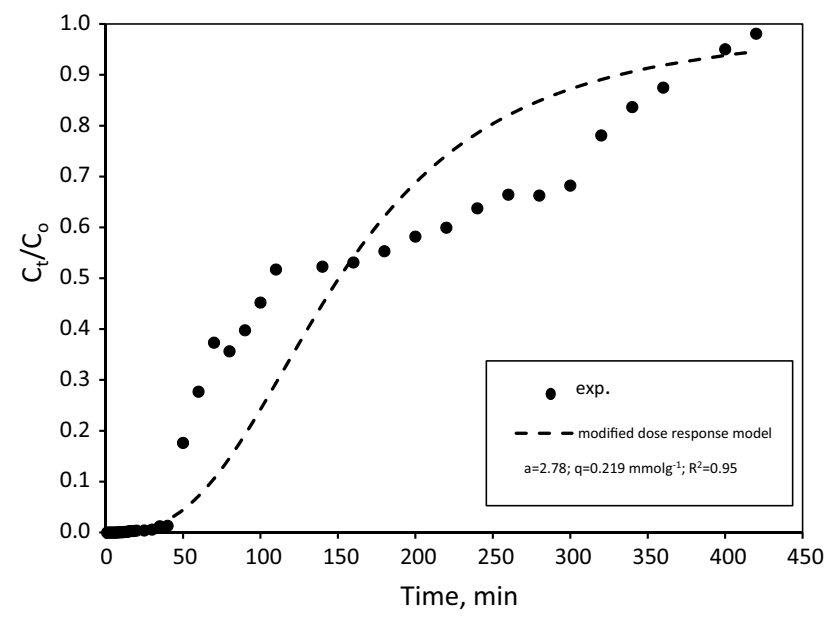

Fig. 7 Breakthrough curve for $\mathrm{Pb}^{2+}$ adsorption (bed height $=5 \mathrm{~cm}$; flow rate of $1 \mathrm{~mL} \mathrm{~min}{ }^{-1}$; initial concentration $=0.5 \mathrm{mM}$; particle size $=0.6 \mathrm{~mm} ; \mathrm{pH} 6.0$ ) found to be $43 \%$ and $0.007 \mathrm{mmol} \mathrm{g}^{-1}$, respectively. The adsorption capacity for $\mathrm{Pb}^{2+}$ uptake onto the biochar was much less than the batch mode results (Fig. 6). Similar observations were reported by Qaiser et al. (2009) and Ahmad and Hameed (2010). This can be attributed to the insufficient contact time $\left(t_{\mathrm{b}}\right)$ which did not allow the $\mathrm{Pb}^{2+}$ to diffuse into biochar particles and therefore, the adsorption process could be still ongoing and adsorption equilibrium had not been reached. This was consistent with the kinetics results where the required time to reach equilibrium was about $360 \mathrm{~min}$.

\section{Mathematical modelling of fixed bed column adsorption}

Several mathematical models have been developed to describe the breakthrough curve for column design including Adams-Bohart, Thomas, and modified dose-response models. Thomas model (Eq. 11) is based on the assumptions of Langmuir's kinetics of adsorption-desorption and negligible axial and radial dispersion (Malkoc and Nuhoglu 2006):

$\ln \left(\frac{C_{\mathrm{o}}}{C_{\mathrm{t}}}-1\right)=\frac{K_{\mathrm{TH}} q_{\mathrm{o}} m}{Q}-K_{\mathrm{TH}} C_{\mathrm{o}} t$

where $C_{\mathrm{o}}$ is influent concentration $(\mathrm{mM}) ; C_{\mathrm{t}}$ is equilibrium concentration $(\mathrm{mM})$ at time $t(\mathrm{~min}) ; K_{\mathrm{TH}}$ is Thomas constant $\left.\left[\mathrm{L} \min ^{-1} \mathrm{mmol}^{-1}\right)\right] ; Q$ is volumetric flow rate $\left(\mathrm{L} \mathrm{min}{ }^{-1}\right)$;

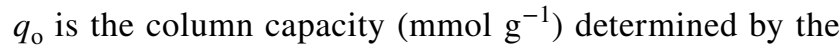
Thomas model; $m$ is mass of biochar $(\mathrm{g})$. The $K_{\mathrm{TH}}$ coefficient and the $q_{\mathrm{o}}$ can be determined from the slope and the intercept of the straight line obtained by plotting $\ln \left[\left(C_{\mathrm{o}} / C_{\mathrm{t}}\right)-1\right]$ against $t$.

Adams-Bohart model (Eq. 12) assumes that equilibrium is not instantaneous and the adsorption rate is proportional to the adsorption capacity remaining on the adsorbent (Goel et al. 2005).

$t=\frac{N_{\mathrm{o}} Z}{C_{\mathrm{o}} v}-\ln \left(\left(\frac{C_{\mathrm{o}}}{C_{\mathrm{t}}}\right)-1\right) \frac{1}{K_{\mathrm{AB}} C_{\mathrm{o}}}$

where $t$ is the breakthrough time ( $\mathrm{min}) ; C_{\mathrm{o}}$ the influent concentration $(\mathrm{mM}) ; C_{\mathrm{t}}$ the concentration at breakthrough $(\mathrm{mM}) ; N_{\mathrm{o}}$ the adsorptive capacity $\left(\mathrm{mmol} \mathrm{L}^{-1}\right) ; Z$ is bed depth $(\mathrm{cm}) ; v$ the linear flow rate $\left(\mathrm{cm} \mathrm{min}^{-1}\right) ; K_{\mathrm{AB}}$ is the Adams-Bohart rate constant [L (mmol min $)^{-1}$ ]. Both $K_{\mathrm{AB}}$ and $N_{\mathrm{o}}$ can be determined from the slope and the intercept of the straight line obtained by plotting $\ln \left[\left(C_{\mathrm{o}} / C_{\mathrm{t}}\right)-1\right]$ against $t$.

The modified dose-response model (Eq. 13) is a simplified mathematical model which can reduce the error resulting from Thomas model, particularly at lower or higher time periods of the breakthrough curve (Yan et al. 2001).

$\ln \left[\frac{C_{\mathrm{t}}}{C_{\mathrm{o}}-C_{\mathrm{t}}}\right]=a \ln C_{\mathrm{o}} Q t-a \ln q m$ 
where $t$ is the breakthrough time (min); $C_{\mathrm{o}}$ is influent concentration $(\mathrm{mM}) ; C_{\mathrm{t}}$ is concentration at breakthrough $(\mathrm{mM})$; $q$ the adsorptive capacity $\left(\mathrm{mmol} \mathrm{g}^{-1}\right) ; m$ biochar weight, $(\mathrm{g}) ; a$ is the modified dose-response model constant. Both $a$ and $q$ can be determined from the slope and the intercept of the straight line obtained by plotting $\ln \left[C_{\mathrm{t}} /\left(C_{\mathrm{o}}-C_{\mathrm{t}}\right)\right]$ against $\ln \left(C_{0} Q t\right)$.

Both Adams-Bohart $\left(R^{2}=0.76\right)$ and Thomas model $\left(R^{2}=0.77\right)$ showed reasonable fit to the experimental data. However, adsorption experimental data showed better agreement with the modified dose-response model $\left(R^{2}=0.95\right)$ as shown in Fig. 7. Other researchers also reported that the modified dose-response model can more adequately describe heavy metal adsorption (Yan et al. 2001; Vijayaraghavan and Prabu 2006). According to the modified dose-response model, the maximum $\mathrm{Pb}^{2+}$ adsorption capacity $(q)$ in the packed column was found to be $0.219 \mathrm{mmol} \mathrm{g}^{-1}$, which is less than the Langmuir maximum adsorption capacity obtained from the batch experiments $\left(0.360 \mathrm{mmol} \mathrm{g}^{-1}\right)$. However, Fig. 7 shows that the adsorption of $\mathrm{Pb}^{2+}$ onto the biochar displays a twostage phenomenon which is consistent with our findings from the batch experiment (Fig. 5). The assumed shape of the modified dose-response model does not capture this phenomenon which may have led to inaccurate prediction of the $q$ value.

\section{Adsorption thermodynamics}

Adsorption thermodynamic of $\mathrm{Pb}^{2+}$ was evaluated by using Gibbs free energy change $\left(\Delta G^{\circ}\right)$. The calculated Gibbs free energy value of $\left(\Delta G^{\circ}=-29.1\right)$ indicated that the adsorption reaction of $\mathrm{Pb}^{2+}$ was a spontaneous process (Anastopoulos and Kyzas 2016).

\section{Desorption studies}

Figure 8 shows the results of the desorption experiments. Desorption of $\mathrm{Pb}^{2+}$ from the biochar using DI water as eluent agent was negligible $\left(0.001 \mathrm{mmol} \mathrm{g}^{-1}, 2.1 \%\right)$ compared to measured amount of adsorbed $\left(0.046 \mathrm{mmol} \mathrm{g}^{-1}\right)$. $\mathrm{HCl}$ was more effective, causing $23 \%\left(0.011 \mathrm{mmol} \mathrm{g}^{-1}\right)$ of the adsorbed lead to desorb. However, a solution composed of $0.01 \mathrm{M} \mathrm{HCl}$ and $0.1 \mathrm{M} \mathrm{CaCl}_{2}$ was the most effective with $55 \%\left(0.026 \mathrm{mmol} \mathrm{g}^{-1}\right)$ desorption efficiency. Biochar has long-term stability in the environment due to its physicochemical properties and its chemical stability (Harvey et al. 2011; Méndez et al. 2012). Therefore, the results suggest that the loaded biochar may be suitable for disposal into

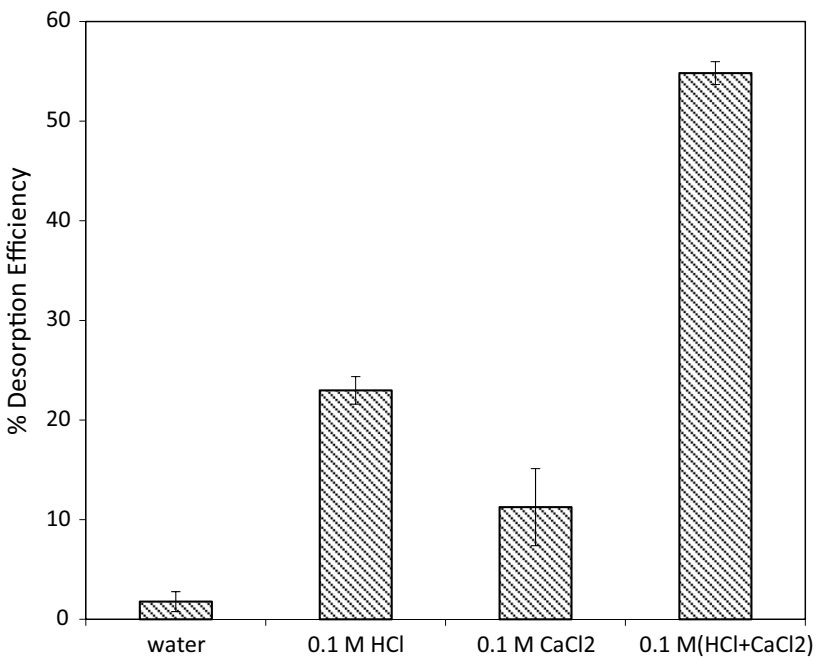

Fig. 8 Desorption studies of laden biochar DSB550-3 with $\mathrm{Pb}^{2+}$ ions

designated landfill if it is protected from acidic leachate. Furthermore, if not disposed of in landfill, the exhausted biochar may be regenerated using successive elution with $\mathrm{HCl}$ and $\mathrm{CaCl}_{2}$.

\section{Conclusions}

Lead adsorption on date seed-derived biochar was studied using batch and column experiments. Regression analysis showed that the biochar adsorption capacity for $\mathrm{Pb}^{2+}$ was positively and linearly correlated with the pyrolysis temperature and heating time. Biochar prepared at $550{ }^{\circ} \mathrm{C}$ for $3 \mathrm{~h}$ had the highest $\mathrm{Pb}^{2+}$ adsorption capacity. The amount of $\mathrm{Pb}^{2+}$ adsorbed was found to vary significantly with initial $\mathrm{Pb}^{2+}$ concentration, solution $\mathrm{pH}$, and contact time. Langmuir and Freundlich isotherm models were a good fit $\left(R^{2}\right.$ 0.97) for $\mathrm{Pb}^{2+}$ adsorption onto biochar. Maximum adsorption capacity of $0.360 \mathrm{mmol} \mathrm{g}^{-1}$ was obtained at $\mathrm{pH}$ of 6.0. Adsorption kinetics showed that the adsorption reaction reached equilibrium after $6 \mathrm{~h}$. Experimental data showed good agreement with the pseudo-second-order kinetic reaction model $\left(R^{2} 0.94\right)$. The breakthrough curve obtained from the column study showed good agreement with the predicted results obtained from the modified dose-response model $\left(R^{2} 0.95\right)$. The adsorption capacity in the column experiment was found to be $0.219 \mathrm{mmol} \mathrm{g}^{-1}$. The negative adsorption standard free energy changes indicate that the adsorption reaction is spontaneous process. Based on batch and column studies, biochar has the potential to be an efficient sorbent for $\mathrm{Pb}^{2+}$ removal from aqueous solution. 
Acknowledgements Zainab is a Ph.D. student sponsored by the higher committee for education development in Iraq (HCED). The authors would like to thank Mr. Scott Byrnes, Mr. Alan White, Mr. James Cameron from Griffith University and Ms. Jasmin Rößler from Technische Universität Braunschweig, Germany, for their assistance.

Open Access This article is distributed under the terms of the Creative Commons Attribution 4.0 International License (http://creativeco mmons.org/licenses/by/4.0/), which permits unrestricted use, distribution, and reproduction in any medium, provided you give appropriate credit to the original author(s) and the source, provide a link to the Creative Commons license, and indicate if changes were made.

\section{References}

Abdulkarim M, Abu Al-Rub F (2004) Adsorption of lead ions from aqueous solution onto activated carbon and chemically-modified activated carbon prepared from date pits. Adsorpt Sci Technol 22(2):119-134. https://doi.org/10.1260/026361704323150908

Ahmad AA, Hameed BH (2010) Fixed-bed adsorption of reactive azo dye onto granular activated carbon prepared from waste. J Hazard Mater 175(1):298-303. https://doi.org/10.1016/j.jhazm at.2009.10.003

Ahmad T, Danish M, Rafatullah M, Ghazali A, Sulaiman O, Hashim R, Ibrahim MNM (2012) The use of date palm as a potential adsorbent for wastewater treatment: a review. Environ Sci Pollut Res 19(5):1464-1484. https://doi.org/10.1007/s11356-011-0709-8

Ahmed MJ, Theydan SK (2012) Physical and chemical characteristics of activated carbon prepared by pyrolysis of chemically treated date stones and its ability to adsorb organics. Powder Technol 229:237-245. https://doi.org/10.1016/j.powtec.2012.06.043

Al-Haidary AMA, Zanganah FH, Al-Azawi SR, Khalili FI, Al-Dujaili AH (2011) A study on using date palm fibers and leaf base of palm as adsorbents for $\mathrm{Pb}(\mathrm{II})$ ions from its aqueous solution. Water Air Soil Pollut 214(1-4):73-82. https://doi.org/10.1007/ s11270-010-0405-1

Alhamed YA, Bamufleh HS (2009) Sulfur removal from model diesel fuel using granular activated carbon from dates' stones activated by $\mathrm{ZnCl} 2$. Fuel 88(1):87-94. https://doi.org/10.1016/j. fuel.2008.07.019

Alhashimi HA, Aktas CB (2017) Life cycle environmental and economic performance of biochar compared with activated carbon: a meta-analysis. Resour Conserv Recycl 118:13-26. https://doi. org/10.1016/j.resconrec.2016.11.016

Al-Shahib W, Marshall RJ (2003) The fruit of the date palm: its possible use as the best food for the future? Int J Food Sci Nutr 54(4):247-259. https://doi.org/10.1080/09637480120091982

Al-Wabel MI, Al-Omran A, El-Naggar AH, Nadeem M, Usman AR (2013) Pyrolysis temperature induced changes in characteristics and chemical composition of biochar produced from conocarpus wastes. Biores Technol 131:374-379. https://doi.org/10.1016/j. biortech.2012.12.165

American Standard Test Method (2011) Standard test method for determination of contact $\mathrm{pH}$ with activated carbon (ASTM D6851). https://doi.org/10.1520/d6851-02r11

Anastopoulos I, Kyzas GZ (2016) Are the thermodynamic parameters correctly estimated in liquid-phase adsorption phenomena? J Mol Liq 218:174-185. https://doi.org/10.1016/j.molliq.2016.02.059

Australian Government National Health and Medical Research Council (2015) National water quality management strategy (NHMRC): Australian drinking waste guideline 6 version 3.1. https://www. nhmrc.gov.au/_files_nhmrc/publications/attachments/eh52_austr alian_drinking_water_guidelines_150413.pdf. Accessed 14 Apr 2015

Bledzki AK, Mamun AA, Volk J (2010) Barley husk and coconut shell reinforced polypropylene composites: the effect of fibre physical, chemical and surface properties. Compos Sci Technol 70(5):840 846. https://doi.org/10.1016/j.compscitech.2010.01.022

Boehm HP (2002) Surface oxides on carbon and their analysis: a critical assessment. Carbon 40(2):145-149. https://doi.org/10.1016/ s0008-6223(01)00165-8

Bouchelta C, Medjram MS, Bertrand O, Bellat JP (2008) Preparation and characterization of activated carbon from date stones by physical activation with steam. J Anal Appl Pyrol 82(1):70-77. https://doi.org/10.1016/j.jaap.2007.12.009

Bouhamed F, Elouear Z, Bouzid J (2012) Adsorptive removal of copper(II) from aqueous solutions on activated carbon prepared from Tunisian date stones: equilibrium, kinetics and thermodynamics. J Taiwan Inst Chem Eng 43(5):741-749. https://doi. org/10.1016/j.jtice.2012.02.011

Chen B, Chen Z, Lv S (2011a) A novel magnetic biochar efficiently sorbs organic pollutants and phosphate. Biores Technol 102(2):716-723. https://doi.org/10.1016/j.biortech.2010.08.067

Chen X, Chen G, Chen L, Chen Y, Lehmann J, McBride MB, Hay AG (2011b) Adsorption of copper and zinc by biochars produced from pyrolysis of hardwood and corn straw in aqueous solution. Biores Technol 102(19):8877-8884. https://doi. org/10.1016/j.biortech.2011.06.078

Chen T, Zhang Y, Wang H, Lu W, Zhou Z, Zhang Y, Ren L (2014) Influence of pyrolysis temperature on characteristics and heavy metal adsorptive performance of biochar derived from municipal sewage sludge. Biores Technol 164:47-54. https://doi. org/10.1016/j.biortech.2014.04.048

Chen J, Zhang D, Zhang H, Ghosh S, Pan B (2017) Fast and slow adsorption of carbamazepine on biochar as affected by carbon structure and mineral composition. Sci Total Environ 579:598605. https://doi.org/10.1016/j.scitotenv.2016.11.052

Cheng Q, Huang Q, Khan S, Liu Y, Liao Z, Li G, Ok YS (2016) Adsorption of $\mathrm{Cd}$ by peanut husks and peanut husk biochar from aqueous solutions. Ecol Eng 87:240-245. https://doi. org/10.1016/j.ecoleng.2015.11.045

Claoston N, Samsuri AW, Ahmad Husni MH, Mohd Amran MS (2014) Effects of pyrolysis temperature on the physicochemical properties of empty fruit bunch and rice husk biochars. Waste Manage Res 32(4):331-339. https://doi.org/10.1177/0734242x14525822

Danish M, Hashim R, Rafatullah M, Sulaiman O, Ahmad A (2011) Adsorption of $\mathrm{Pb}(\mathrm{II})$ ions from aqueous solutions by date bead carbon activated with $\mathrm{ZnCl}_{2}$. Clean Soil Air Water 39(4):392-399. https://doi.org/10.1002/clen.201000185

El Hanandeh A, Abu-Zurayk RA, Hamadneh I, Al-Dujaili AH (2016) Characterization of biochar prepared from slow pyrolysis of Jordanian olive oil processing solid waste and adsorption efficiency of $\mathrm{Hg}^{2+}$ ions in aqueous solutions. Water Sci Technol 74(8):18991910. https://doi.org/10.2166/wst.2016.378

El-Hendawy ANA (2009) The role of surface chemistry and solution $\mathrm{pH}$ on the removal of $\mathrm{Pb}^{2+}$ and $\mathrm{Cd}^{2+}$ ions via effective adsorbents from low-cost biomass. J Hazard Mater 167(1):260-267. https:// doi.org/10.1016/j.jhazmat.2008.12.118

El-Naas MH, Al-Zuhair S, Alhaija MA (2010) Reduction of COD in refinery wastewater through adsorption on date-pit activated carbon. J Hazard Mater 173(1):750-757. https://doi.org/10.1016/j. jhazmat.2009.09.002

Food and Agriculture Organization of the United Nations FAO (2014) Crop production. USA. http://www.fao.org/statistics/databases/en/

Girgis BS, El-Hendawy ANA (2002) Porosity development in activated carbons obtained from date pits under chemical activation with phosphoric acid. Microporous Mesoporous Mater 52(2):105-117. https://doi.org/10.1016/s1387-1811(01)00481-4 
Goel J, Kadirvelu K, Rajagopal C, Garg VK (2005) Removal of lead(II) by adsorption using treated granular activated carbon: batch and column studies. J Hazard Mater 125(1):211-220. https://doi. org/10.1016/j.jhazmat.2005.05.032

Han Y, Boateng AA, Qi PX, Lima IM, Chang J (2013) Heavy metal and phenol adsorptive properties of biochars from pyrolyzed switchgrass and woody biomass in correlation with surface properties. J Environ Manage 118:196-204. https://doi.org/10.1016/j.jenvm an.2013.01.001

Harvey OR, Herbert BE, Rhue RD, Kuo LJ (2011) Metal interactions at the biochar-water interface: energetics and structure-sorption relationships elucidated by flow adsorption microcalorimetry. Environ Sci Technol 45(13):5550-5556. https://doi.org/10.1021/ es104401h

Inyang M, Gao B, Ding W, Pullammanappallil P, Zimmerman AR, Cao $X$ (2011) Enhanced lead sorption by biochar derived from anaerobically digested sugarcane bagasse. Sep Sci Technol 46(12):19501956. https://doi.org/10.1080/01496395.2011.584604

Jia M, Wang F, Bian Y, Jin X, Song Y, Kengara FO, Jiang X (2013) Effects of $\mathrm{pH}$ and metal ions on oxytetracycline sorption to maizestraw-derived biochar. Biores Technol 136:87-93. https://doi. org/10.1016/j.biortech.2013.02.098

Jibril B, Houache O, Al-Maamari R, Al-Rashidi B (2008) Effects of $\mathrm{H}_{3} \mathrm{PO}_{4}$ and $\mathrm{KOH}$ in carbonization of lignocellulosic material. J Anal Appl Pyrol 83(2):151-156. https://doi.org/10.1016/j. jaap.2008.07.003

Joseph SD, Downie A, Munroe P, Crosky A, Lehmann J (2007) Biochar for carbon sequestration, reduction of greenhouse gas emissions and enhancement of soil fertility: a review of the materials science. In: Proceedings of the Australian combustion symposium, pp 130-133

Kim WK, Shim T, Kim YS, Hyun S, Ryu C, Park YK, Jung J (2013) Characterization of cadmium removal from aqueous solution by biochar produced from a giant Miscanthus at different pyrolytic temperatures. Biores Technol 138:266-270. https://doi. org/10.1016/j.biortech.2013.03.186

Kloss S, Zehetner F, Dellantonio A, Hamid R, Ottner F, Liedtke V, Soja G (2012) Characterization of slow pyrolysis biochars: effects of feedstocks and pyrolysis temperature on biochar properties. J Environ Qual 41(4):990-1000. https://doi.org/10.2134/jeq2011.0070

Kobya M, Demirbas E, Senturk E, Ince M (2005) Adsorption of heavy metal ions from aqueous solutions by activated carbon prepared from apricot stone. Biores Technol 96(13):1518-1521. https://doi. org/10.1016/j.biortech.2004.12.005

Li B, Yang L, Wang CQ, Zhang QP, Liu QC, Li YD, Xiao R (2017) Adsorption of $\mathrm{Cd}(\mathrm{II})$ from aqueous solutions by rape straw biochar derived from different modification processes. Chemosphere 175:332-340. https://doi.org/10.1016/j.chemosphere.2017.02.061

Liu Z, Zhang FS (2009) Removal of lead from water using biochars prepared from hydrothermal liquefaction of biomass. J Hazard Mater 167(1):933-939. https://doi.org/10.1016/j.jhazm at.2009.01.085

Liu W, Tian J, Chen L, Guo Y (2017) Temporal and spatial characteristics of lead emissions from the lead-acid battery manufacturing industry in China. Environ Pollut 220:696-703. https://doi. org/10.1016/j.envpol.2016.10.031

Mahdi Z, El Hanandeh A, Yu Q (2016) Influence of pyrolysis conditions on surface characteristics and methylene blue adsorption of biochar derived from date seed biomass. Waste Biomass Valoriz. https://doi.org/10.1007/s12649-016-9714-y

Maheshwari U, Gupta S (2016) Removal of Cr(VI) from wastewater using activated neem bark in a fixed-bed column: interference of other ions and kinetic modelling studies. Desalin Water Treat 57(18):8514-8525

Malkoc E, Nuhoglu Y (2006) Removal of Ni(II) ions from aqueous solutions using waste of tea factory: adsorption on a fixed-bed column. J Hazard Mater 135(1):328-336. https://doi. org/10.1016/j.jhazmat.2005.11.070

McCarl BA, Peacocke C, Chrisman R, Kung CC, Sands RD (2009) Economics of biochar production, utilization and greenhouse gas offsets. In: Lehmann J, Joseph AS (eds) Biochar for environmental management: science and technology. Earthscan, London, pp $341-358$

Méndez A, Gómez A, Paz-Ferreiro J, Gascó G (2012) Effects of sewage sludge biochar on plant metal availability after application to a Mediterranean soil. Chemosphere 89(11):1354-1359. https:// doi.org/10.1016/j.chemosphere.2012.05.092

Nasser RA, Salem MZ, Hiziroglu S, Al-Mefarrej HA, Mohareb AS, Alam M, Aref IM (2016) Chemical analysis of different parts of date palm (Phoenix dactylifera L.) using ultimate, proximate and thermo-gravimetric techniques for energy production. Energies 9(5):374. https://doi.org/10.3390/en9050374

Nunes CA, Guerreiro MC (2011) Estimation of surface area and pore volume of activated carbons by methylene blue and iodine numbers. Quim Nova 34(3):472-476. https://doi.org/10.1590/s0100 $-40422011000300020$

Peruchi LM, Fostier AH, Rath S (2015) Sorption of norfloxacin in soils: analytical method, kinetics and Freundlich isotherms. Chemosphere 119:310-317. https://doi.org/10.1016/j.chemospher e.2014.06.008

Qaiser S, Saleemi AR, Umar M (2009) Biosorption of lead from aqueous solution by Ficus religiosa leaves: batch and column study. J Hazard Mater 166(2):998-1005. https://doi.org/10.1016/j.jhazm at.2008.12.003

Reddy DHK, Lee SM (2014) Magnetic biochar composite: facile synthesis, characterization, and application for heavy metal removal. Colloids Surf A 454:96-103. https://doi.org/10.1016/j.colsu rfa.2014.03.105

Sait HH, Hussain A, Salema AA, Ani FN (2012) Pyrolysis and combustion kinetics of date palm biomass using thermogravimetric analysis. Biores Technol 118:382-389. https://doi.org/10.1016/j. biortech.2012.04.081

Sekar M, Sakthi V, Rengaraj S (2004) Kinetics and equilibrium adsorption study of lead(II) onto activated carbon prepared from coconut shell. J Colloid Interface Sci 279(2):307-313. https://doi. org/10.1016/j.jcis.2004.06.042

Vijayaraghavan K, Prabu D (2006) Potential of Sargassum wightii biomass for copper(II) removal from aqueous solutions: application of different mathematical models to batch and continuous biosorption data. J Hazard Mater 137(1):558-564. https://doi. org/10.1016/j.jhazmat.2006.02.030

Wang Y, Liu R (2017) Comparison of characteristics of twenty-one types of biochar and their ability to remove multi-heavy metals and methylene blue in solution. Fuel Process Technol 160:55-63. https://doi.org/10.1016/j.fuproc.2017.02.019

Yakkala K, Yu MR, Roh H, Yang JK, Chang YY (2013) Buffalo weed (Ambrosia trifida L. var. trifida) biochar for cadmium(II) and lead(II) adsorption in single and mixed system. Desalin Water Treat 51(40-42):7732-7745. https://doi.org/10.1080/19443 994.2013 .792546

Yan G, Viraraghavan T, Chen M (2001) A new model for heavy metal removal in a biosorption column. Adsorpt Sci Technol 19(1):2543. https://doi.org/10.1260/0263617011493953

Zhang W, Lo IM (2006) EDTA-enhanced washing for remediation of $\mathrm{Pb}$ - and/or Zn-contaminated soils. J Environ Eng 132(10):1282-1288. https://doi.org/10.1061/ (asce)0733-9372(2006)132:10(1282)

Publisher's Note Springer Nature remains neutral with regard to jurisdictional claims in published maps and institutional affiliations. 